that their failure to detect a complement-fixation antibody response is evidence that an allergic reaction or a previous infection had not taken place. In our own series (Scott and Gardner, 1970), and in a larger series yet to be published, we have shown that infants of 6 weeks and onwards can respond to infection by the rapid production of $\mathrm{RS}$ neutralizing antibodies in their secretions in intervals of even less than 7 days. We find this, and the presence of detectable antibody in the secretion at onset of bronchiolitis in approximately $50 \%$ of cases, far more convincing evidence of the responsiveness of young infants to infection and consistent with bronchiolitis being a second infection. As children get older, repeated exposure to RS virus could lead to desensitization by the production of large amounts of specific IgG.

We hope Dr. Ross and her colleagues will extend their studies in the first 3 months so that we can increase our knowledge of what we feel is a critical period for our understanding of pathogenesis of bronchiolitis.

P. S. GARDNER, J. MCQUILLIN, and S. D. M. COURT Department of Child Health, The University of Newcastle upon Tyne, Newcastle upon Tyne NE1 4LP.

REFERENCES

Gardner, P. S., McQuillin, J., and Court, S. D. M. (1970). Speculation on pathogenesis in death from respiratory syncytial virus infection. British Medical fournal, 1, 327.

Kim, H. W., Bellanti, J. A., Arrobio, J. O., Mills, J., Brandt, C. D., Chanock, R. M., and Parrott, R. H. (1969). Respiratory syncytial virus neutralizing activity in nasal secretions following natural infection. Proceedings of the Society for Experimental Biology and Medicine, 131, 658.

Neligan, G. A., Steiner, H., Gardner, P. S., and McQuillin, J. (1970). Respiratory syncytial virus infection of the newborn. British Medical fournal, 3, 146.

Scott, R., and Gardner, P. S. (1970). Respiratory syncytial virus neutralising activity in nasopharyngeal secretions. fournal of Hygiene, 68, 581.

We showed the above letter to the authors, whose comments follow:

There are two misinterpretations of our paper in the letter by Gardner and his colleagues. Firstly, we did not claim that CF was as sensitive as neutralization but 'as reliable as and more convenient than neutralization tests for diagnosis of acute respiratory infections due to RS virus'. Secondly, our suggestion that bronchiolitis in children under 3 months was probably not a secondary infection was not based on 'failure to detect' a complement fixation antibody response but on the lack of 'boost' responses in this youngest group.

In the paper cited in their letter (Scott and Gardner, 1970), only 30 patients were studied and from only 10 was a second secretion obtained; in only 4 of these 10 was there a fourfold or greater rise in neutralizing activity. This seems to afford no proof of secondary as opposed to primary infection.

CONSTANCE A. C. ROSS and

I. W. PINKERTON

Regional Virus Laboratory, Ruchill Hospital, Glasgow G20 9NB.

\section{Growth Pattern in a Boy with Thyroxine-binding Globulin Deficiency}

Sir,

We read with interest the article by J. L. Penfold, G. M. Kneebone, M. Wellby, and R. K. Oldfield, on 'Growth Retardation and Thyroxine-binding Globulin Deficiency' in the February 1971 issue (p. 115). While they document short stature in terms of a single height measurement, they make no reference to the more important parameter of growth; namely, how fast is the patient growing at this time? We have followed for 6 years the growth pattern in a boy first diagnosed at 13 months of age. No other such longitudinal study has been reported previously.

\section{Case Report}

N.F. is the only child in the family. Pregnancy and delivery were normal. Birthweight at term was $2608 \mathrm{~g}$. Jaundice was present for 3 weeks but no cause was found. At 10 months of age, he was found to have dry eczema and no dental eruption but no other abnormal signs. No goitre was present. PBI was $1 \cdot 1 \mu \mathrm{g} /$ $100 \mathrm{ml}$. He was, therefore, admitted for further study at the age of 13 months. The bone age at the left wrist was 6 months. Serum cholesterol was $85 \mathrm{mg} / 100 \mathrm{ml}$. 132 uptake was $24 \cdot 4 \%$ and $19 \%$ at 3 and 5 hours. Total serum plasma protein was $7.5 \mathrm{~g} / 100 \mathrm{ml}$. Electrophoresis of thyroxine binding proteins showed absent TBG, slight increase in thyroxine binding albumin (TBA), and marked increase in thyroxine binding prealbumin (TBPA) (Fig. 1.) Because of the normal radioactive iodine uptake and the apparent clinical euthyroid state, no therapy was given. The patient was followed at intervals. His growth in height and weight are shown in Fig. 2. At 2 years 3 months, he had 16 teeth and was saying a few words. Bone age was 16 months. At $44 / 12$ years, his bone age was $3 \frac{1}{2}$ years. The patient was now shown to be deaf in the right ear only, for which there was no apparent cause. At $55 / 12$ years, some thyroid studies were repeated. ${ }^{132}$ I uptake was $31 \%$ and $33 \%$ at 3 and $4 \frac{1}{2}$ hours. $\mathrm{T}_{3}$ sephadex uptake was $750 \%(\mathrm{~N}=70$ to $140 \%)$. $\mathrm{PBI}$ was $2 \cdot 3 \mu \mathrm{g} / 100 \mathrm{ml}(\mathrm{N}=4$ to 8$)$. Free thyroxine index was $17 \cdot 2$. These results were considered to be consistent with the earlier diagnosis of low or absent TBG. When last seen at the age of $610 / 12$ years, the patient had normal dental age and a bone age of $6 \frac{1}{2}$ years. His mental development has remained normal. Though no therapy was instituted, the patient has grown at a constant rate each year and has followed a pattern which is parallel to but just below the third centile line. His bone age though initially delayed is now within normal limits. He did show early clinical features which might have suggested hypothyroidism, but subsequent tests, follow-up, and clinical features have excluded this diagnosis. The other 11 previously reported cases or families (some patients over 50 years 
N.F.

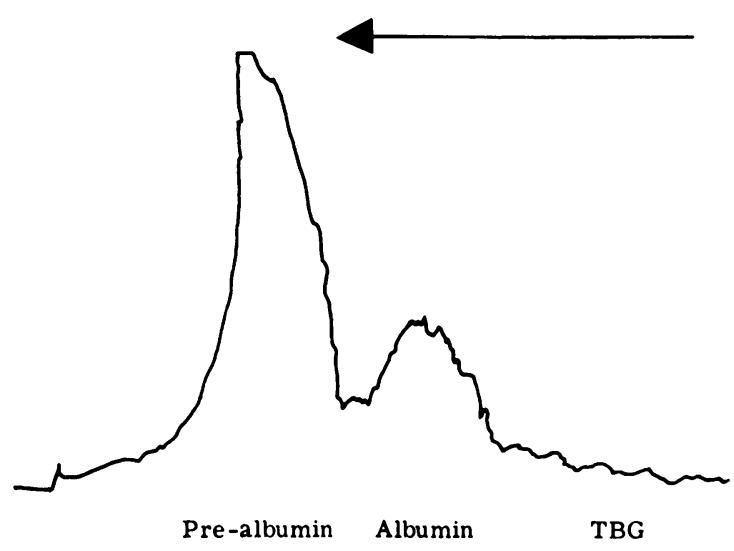

NORMAL

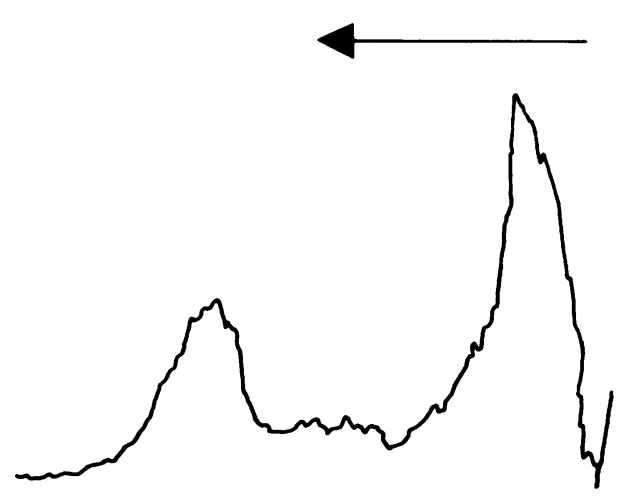

Pre-albumin Albumin

FiG. 1.-Electrophoresis of thyroxine-binding proteins.
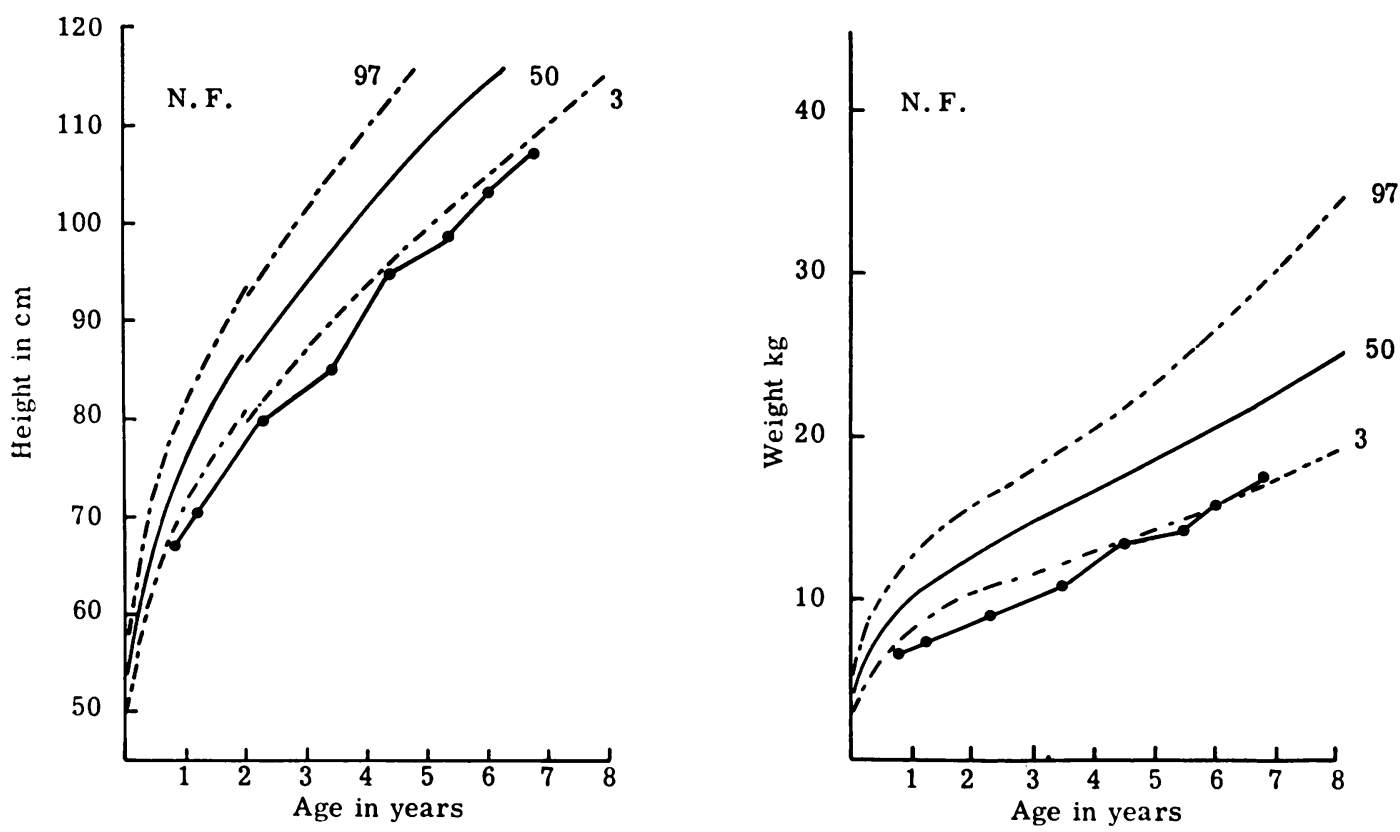

FIG. 2.-Height and weight chart.

of age) have not shown clinical evidence of hypothyroidism. Unlike the report by Penfold et al., it has not been possible to study the parents and relatives of this patient.
SALVATORE RAITI and GEORGE H. NEWNS The Hospital for Sick Children, Great Ormond Street, 